\title{
Mixed Phenotype Acute Leukemia, T/Myeloid, Not Otherwise Specified
}

National Cancer Institute

\section{Source}

National Cancer Institute. Mixed Phenotype Acute Leukemia, T/Myeloid, Not Otherwise Specified. NCI Thesaurus. Code C82213.

A rare mixed phenotype acute leukemia in which the blasts express T-lymphoid and myeloid lineage markers but are negative for MLL translocation and t(9;22)(q34;q11.2) translocation. The prognosis is usually unfavorable. 